\title{
Phenotypic and genotypic drug resistance profile of Salmonella serovars isolated from poultry farm and processing units located in and around Mumbai city, India
}

\author{
R. N. Waghamare ${ }^{1}$, A. M. Paturkar ${ }^{1}$, V. M. Vaidya ${ }^{1}$, R. J. Zende ${ }^{1}$, Z. N. Dubal' ${ }^{2}$ A. Dwivedi and R. V. Gaikwad ${ }^{1}$
}

1. Department of Veterinary Public Health, Bombay Veterinary College, Parel, Mumbai, Maharashtra, India; 2. Department of Veterinary Public Health, ICAR - Indian Veterinary Research Institute, Izatnagar, Bareilly, Uttar Pradesh, India. Corresponding author: R. N. Waghamare, e-mail: rupeshwaghmare@gmail.com

Co-authors: AMP: ashishpaturkar@gmail.com, VMV: vilasmvaidya@gmail.com, RJZ: ravindrazende@gmail.com, ZND: drzunjar@yahoo.co.in, AD: anamika6392@gmail.com, RVG: drrvg2001@yahoo.com

Received: 26-08-2018, Accepted: 25-10-2018, Published online: 16-12-2018

doi: 10.14202/vetworld.2018.1682-1688 How to cite this article: Waghamare RN, Paturkar AM, Vaidya VM, Zende RJ, Dubal ZN, Dwivedi A, Gaikwad RV (2018). Phenotypic and genotypic drug resistance profile of Salmonella serovars isolated from poultry farm and processing units located in and around Mumbai city, India, Veterinary World, 11(12): 1682-1688.

\begin{abstract}
Background and Aim: The extensive use of antimicrobials in poultry has led to an increase in bacterial multidrug resistance, and the emergence of multidrug-resistant nontyphoidal Salmonella is a global problem. This study was performed to detect antibiotic-resistant Salmonella serovars in poultry farming and processing environment.

Materials and Methods: A total of 956 various samples, comprising 432 farm origin, 324 poultry processing stage wise and environmental, and 154 product processing stages and environmental samples, were collected from poultry farms and processing units located in and around Mumbai city. Of a total of 71 recovered isolates, 42 randomly selected Salmonella isolates were subjected for antibiotic susceptibility testing by disk diffusion method and serotyping. A total of 31 serotypically confirmed isolates were characterized for the presence of tet $A$, tet $B$, bla $a_{\mathrm{TEM}}$, and CTX-M gene.
\end{abstract}

Results: Higher resistance was recorded against Doxycycline (100\%), followed by Oxytetracycline (97.62\%), Neomycin (88.10\%), Erythromycin (83.33\%), Tetracycline (78.57\%), and Ceftizoxime (35.71\%). Resistance from 0.00 to 26.19 percent was found to antimicrobials, namely Norfloxacin (26.19\%), Ampicillin (21.43\%), Azithromycin (21.43\%), Ciprofloxacin (19.05\%), Colistin (4.76\%), Streptomycin (16.67\%), Cefotaxime (14.19\%), Enrofloxacin (14.29\%), Amoxyclav (14.29\%), Gentamicin (7.14\%), Chloramphenicol (4.76\%), Amikacin (4.76\%), and Ceftazidime (0.0\%). Results demonstrate that the Salmonella Virchow dominated and all serotypes were found to carry Tetracycline resistance gene tetA, 5 isolates were found to be positive for bla $a_{T E M}$, whereas none of the isolates were carrying tet $B$ and CTX-M gene.

Conclusion: This study revealed that there is a significant rise of Tetracycline resistance with the presence of tet $A$ gene in Salmonella spp. which indicates selective pressure for adopting resistance against tetracycline group of antibiotics.

Keywords: multidrug-resistant, poultry, Salmonella spp., tetracycline.

\section{Introduction}

Foodborne risk factors for human health can be recognized from poultry which includes microbiological and chemical risks, wherein Salmonella spp. contamination and residues from veterinary medications are important risks [1]. Microbiological risk factors are so prevailing that they can be found in almost all systems of poultry production [2]. Poultry and poultry products are known reservoirs for these foodborne pathogens, and numerous reports described the prevalence of Salmonella associated with live poultry, production environments, and processing plants [3]. Salmonella has been a pathogen of significance and is a major cause of gastroenteritis in humans [4]. Salmonella illness has linked with exposure

Copyright: Waghamare, et al. Open Access. This article is distributed under the terms of the Creative Commons Attribution 4.0 International License (http://creativecommons.org/licenses/ by/4.0/), which permits unrestricted use, distribution, and reproduction in any medium, provided you give appropriate credit to the original author(s) and the source, provide a link to the Creative Commons license, and indicate if changes were made. The Creative Commons Public Domain Dedication waiver (http:// creativecommons.org/publicdomain/zero/1.0/) applies to the data made available in this article, unless otherwise stated. to meat; a review of the Centers for Disease Control and Prevention 2012 outbreak data indicated that 10 out of 25 outbreaks were related to live poultry, shell eggs, or further processed poultry products [5].

Salmonellosis in animal and human may occur due to the involvement of $>2500$ serovars [6]. In India, Salmonella Virchow, Salmonella Typhimurium, and $S$. Enteritidis are reported as major nontyphoidal Salmonella serovar from poultry [7]. Among veterinary residues, antibiotic residues in meat have been a rising issue in recent years in India. Antibiotics have been used in poultry for the treatment of infections and also to counteract the adverse consequences of stress responses [8]. The presence of antimicrobial residues in meat has several impacts on health aspects to the consumer like possible contribution to the development of antibiotic resistance bacteria [9]. Various workers reported drug resistance genes against tetracycline and broad- and extended-spectrum $\beta$-lactamase antibiotics in Salmonella due to selective pressure [10].

Therefore, the purpose of the present study was to examine the presence of multidrug-resistant (MDR) 
Salmonella spp. in poultry farming and processing establishment. The increasing single and multiple antimicrobial-resistant Salmonella strains isolated from human cases of Salmonellosis have been associated with widespread use of antimicrobial agents in food animal production [11]. This may clearly represent a public health risk by transfer of resistant Salmonella strains to humans through the consumption of contaminated poultry products.

\section{Materials and Methods}

\section{Ethical approval}

Since no animals were used in this study, ethical approval was not needed.

\section{Sampling and study period}

In the present study, for isolation of Salmonella spp., a total of 956 various samples, comprising 432 poultry farm origin, 324 poultry processing stage wise and environmental, and 154 product processing stages and environmental samples, were collected from poultry farms and processing units located in and around Mumbai city during December 2015-December 2017. Bacterial isolates were isolated by IS 5887 (Part 3): 1999 [12]. Bacterial isolates were identified on the basis of cultural characteristics on BGSA and XLD media, Gram staining, and conventional biochemical test. The isolates were further characterized by invA gene as per the method of Rahn et al. [13], to identify pathogenic Salmonella spp. Isolates identified as Salmonellae were sent to Poultry Diagnostics and Research Center, Loni Kalbhor, Pune, for serotyping.

\section{Antimicrobial susceptibility testing}

Randomly selected 42 Salmonella spp. isolates were tested for antimicrobial susceptibility by disk diffusion method (Kirby-Bauer test) using the following randomly selected 19 antimicrobials which were commonly used in animal and humans (HiMedia Laboratories, Pvt., Ltd., Mumbai, India): Gentamicin $(10 \mu \mathrm{g})$, Azithromycin (15 $\mathrm{g})$, Ceftizoxime (30 $\mu \mathrm{g})$, Amikacin $(30 \mu \mathrm{g})$, Amoxyclav $(30 \mu \mathrm{g})$, Norfloxacin $(10 \mu \mathrm{g})$, Oxytetracycline $(30 \mu \mathrm{g})$, Enrofloxacin $(10 \mu \mathrm{g})$, Ciprofloxacin $(5 \mu \mathrm{g})$, Streptomycin $(10 \mu \mathrm{g})$, Colistin
$(10 \mu \mathrm{g})$, Chloramphenicol $(30 \mu \mathrm{g})$, Cefotaxime $(30 \mu \mathrm{g})$, Ceftazidime $(30 \mu \mathrm{g})$, Ampicillin $(10 \mu \mathrm{g})$, Neomycin (30 $\mu \mathrm{g})$, Erythromycin $(15 \mu \mathrm{g})$, Tetracycline $(30 \mu \mathrm{g})$, and Doxycycline $(30 \mu \mathrm{g})$. According to the Clinical and Laboratory Standards Institute [14] guidelines and interpretative criteria and based on inhibition zone, the isolates were categorized as resistance $(\mathrm{R})$, intermediate (I), and sensitive $(\mathrm{S})$.

\section{Detection of antimicrobial resistance genes}

The presence of genes associated with resistance to Tetracycline (tet $A$ and tet $B$ ), broad-spectrum $\beta$-lactamases $\left(b l a_{\mathrm{TEM}}\right)$, and $\beta$-lactamases with extended spectrum (CTX-M) in confirmed 31 serotypes were detected by polymerase chain reaction (PCR) as per the methods [15-17] depicted in Table-1.

\section{Results}

\section{Occurrence of Salmonella spp.}

On screening these 956 samples, 71 positive Salmonella spp. were recovered with the occurrence of $7.4 \%$. All the isolates were further confirmed as Salmonella spp. by amplification of invA gene.

\section{Susceptibility testing through agar disk diffusion method}

Antibiotic susceptibility testing was performed for randomly selected 42 confirmed inv $A$ gene-positive

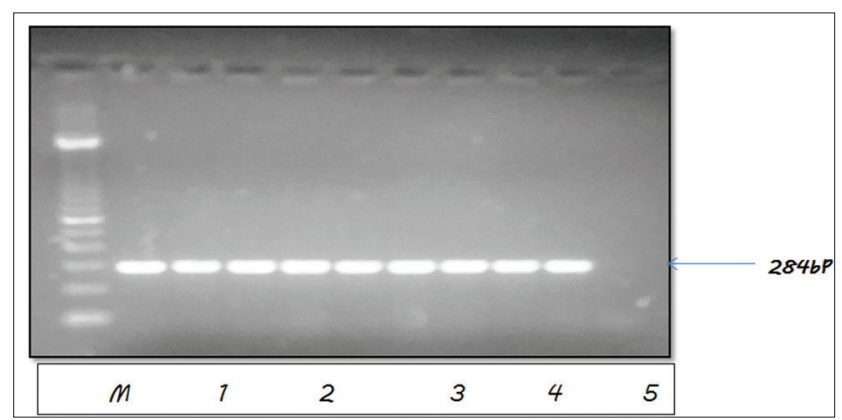

Figure-1: Polymerase chain reaction assay for the detection of virulence gene invA of Salmonella isolates. Lane M: 100 bp standard DNA ladder. Lane 1-9: Isolates positive for invA gene. Lane 10: Negative control.

Table-1: Standardization of PCR method for genotypic characterization of Salmonella spp.

\begin{tabular}{|c|c|c|c|c|c|c|}
\hline S. No. & $\begin{array}{l}\text { Gene } \\
\text { name }\end{array}$ & Target & Primer Sequence $\left(5^{\prime}-3^{\prime}\right)$ & $\begin{array}{l}\text { Thermal profiles for } \\
\text { PCR }\end{array}$ & $\begin{array}{l}\text { Product } \\
\text { Size (bp) }\end{array}$ & Reference \\
\hline 1 & invA & $\begin{array}{l}\text { Invasion- } \\
\text { associated } \\
\text { protein }\end{array}$ & $\begin{array}{l}\text { F: GTGAAATTATCGCCACGTTCGGGCAA } \\
\text { R: TCATCGCACCGTCAAAGGAACC }\end{array}$ & $\begin{array}{l}94^{\circ} \mathrm{C} \times 2 \mathrm{~m} / 94^{\circ} \mathrm{C} \times 30 \mathrm{~s}- \\
65^{\circ} \mathrm{C} \times 60 \mathrm{~s}-72^{\circ} \mathrm{C} \times 120 \mathrm{~s} \\
(30 \mathrm{cycles}) / 72^{\circ} \mathrm{C} \times 5 \mathrm{~m}\end{array}$ & 284 & [13] \\
\hline 2 & $b l a_{\mathrm{TEM}}$ & $\begin{array}{l}\text { Broad- } \\
\text { spectrum } \\
\beta \text {-lactamases }\end{array}$ & $\begin{array}{l}\text { F: ATGAGTATTCAACATTTCCG } \\
\text { R: CTGACAGTTACCAATGCTTA }\end{array}$ & $\begin{array}{l}95^{\circ} \mathrm{C} \times 5 \mathrm{~m} / 95^{\circ} \mathrm{C} \times 60 \mathrm{~s}- \\
55^{\circ} \mathrm{C} \times 60 \mathrm{~s}-72^{\circ} \mathrm{C} \times 60 \mathrm{~s} \\
(35 \mathrm{cycles}) / 72^{\circ} \mathrm{C} \times 7 \mathrm{~m}\end{array}$ & 867 & [15] \\
\hline 3 & tet $A$ & Tetracycline & $\begin{array}{l}\text { F: GCTACATCCTGCTTGCCTTC } \\
\text { R: CATAGATCGCCGTGAAGAGG }\end{array}$ & $\begin{array}{l}95^{\circ} \mathrm{C} \times 5 \mathrm{~m} / 95^{\circ} \mathrm{C} \times 60 \mathrm{~s}- \\
64^{\circ} \mathrm{C} \times 30 \mathrm{~s}-72^{\circ} \mathrm{C} \times 30 \mathrm{~s} \\
(40 \mathrm{cycles}) / 72^{\circ} \mathrm{C} \times 10 \mathrm{~m}\end{array}$ & 210 & [16] \\
\hline 4 & tet $B$ & Tetracycline & $\begin{array}{l}\text { F: TTGGTTAGGGGCAAGTITTG } \\
\text { R: GTAATGGGCCAATAACACCG }\end{array}$ & $\begin{array}{l}95^{\circ} \mathrm{C} \times 5 \mathrm{~m} / 95^{\circ} \mathrm{C} \times 60 \mathrm{~s}- \\
64^{\circ} \mathrm{C} \times 30 \mathrm{~s}-72^{\circ} \mathrm{C} \times 30 \mathrm{~s} \\
(40 \mathrm{cycles}) / 72^{\circ} \mathrm{C} \times 10 \mathrm{~m}\end{array}$ & 659 & [16] \\
\hline 5 & CTX-M & $\begin{array}{l}\beta \text {-lactamases } \\
\text { with extended } \\
\text { spectrum }\end{array}$ & $\begin{array}{l}\text { F: ATGTGCAGYACCAGTAARGTKATGGC } \\
\text { R:TGGGTRAARTARGTSACCAGAAYCA } \\
\text { GCGG }\end{array}$ & $\begin{array}{l}95^{\circ} \mathrm{C} \times 5 \mathrm{~m} / 94^{\circ} \mathrm{C} \times 30 \mathrm{~s}- \\
62^{\circ} \mathrm{C} \times 90 \mathrm{~s}-72^{\circ} \mathrm{C} \times 60 \mathrm{~s} \\
(40 \mathrm{cycles}) / 72^{\circ} \mathrm{C} \times 10 \mathrm{~m}\end{array}$ & 593 & [17] \\
\hline
\end{tabular}

PCR: Polymerase chain reaction 
isolates (Figure-1) with 19 frequently used antibiotics stated earlier. All of the isolates from this study were found to be resistant to more than two antibiotics.

\section{Antimicrobial resistance pattern}

The PCR assay (invA gene) positive 42 Salmonella isolates were tested against 19 commonly used antimicrobials for resistance pattern. Higher resistance was recorded against Doxycycline $(100 \%)$, followed by Oxytetracycline (97.62\%), Neomycin $(88.10 \%)$, Erythromycin $(83.33 \%)$, Tetracycline $(78.57 \%)$, and Ceftizoxime (35.71\%). Resistance was also found to routinely used antimicrobials, namely Norfloxacin (26.19\%), Ampicillin (21.43\%), Azithromycin (21.43), Ciprofloxacin (19.05\%), Streptomycin (16.67\%), Cefotaxime (14.19\%), Enrofloxacin (14.29\%), and Amoxyclav (14.29\%). All the isolates were found susceptible to Ceftazidime. The drugs found to be effective in terms of susceptibility were Colistin $(83.33 \%)$, Chloramphenicol (95.24\%), Gentamicin (88.10\%), and Amikacin (95.24\%). Results are depicted in Table-2.

\section{Serotyping of isolates}

Out of 42 isolates, 31 were identified as S. Virchow (20), Salmonella Newport (6), and $S$. Typhimurium (5), whereas 11 isolates remained untypable, this indicates the dominance of serotype $S$. Virchow in poultry farming and processing system under study.

\section{Charactering of serotypes for the presence of tetA, tetB, bla ${ }_{T E M^{\prime}}$ and CTX-M genes}

All the tested Salmonella serotypes $(\mathrm{n}=31)$ were found to carry Tetracycline resistance gene tetA, whereas none of them were carrying tet $B$ gene. Whereas 5 isolates were found positive for $b l \mathrm{a}_{\mathrm{TEM}}$ indicating resistance against Broad spectrum $\beta$-lactamases, and none of the isolate was found to be carrying CTX-M gene (Table-3 and Figures 2-4). The bla ${ }_{\text {TEM }}$ gene was observed in two isolates from each of $S$. Typhimurium
(NIWH6 and ACWH6) and S. Newport (SCDM4 and RCKS4), while one isolate of $S$. Virchow (RCPD4). The overall occurrence of Tetracycline resistance and broad-spectrum $\beta$-lactamases resistance in Salmonella isolates was 100 and $16.12 \%$, respectively.

\section{Discussion}

Poultry and their environments are act as the major sources of foodborne salmonellosis to human beings. In the present study, an overall occurrence of Salmonella isolation from poultry samples and environment was $7.4 \%$ which is of public health significance.

Although antimicrobials have a distinct advantage in the management of infection and promotion of growth in broilers, indiscriminate and non-judicious extensive use of antimicrobials could lead to the emergence of antimicrobial resistance. This uncontrolled use of drugs may exert selective pressure and promotes the proliferation of drug-resistant strains of Salmonella in poultry production system [18]. This was coupled with poor environmental sanitation and workers personal hygiene in processing could be a

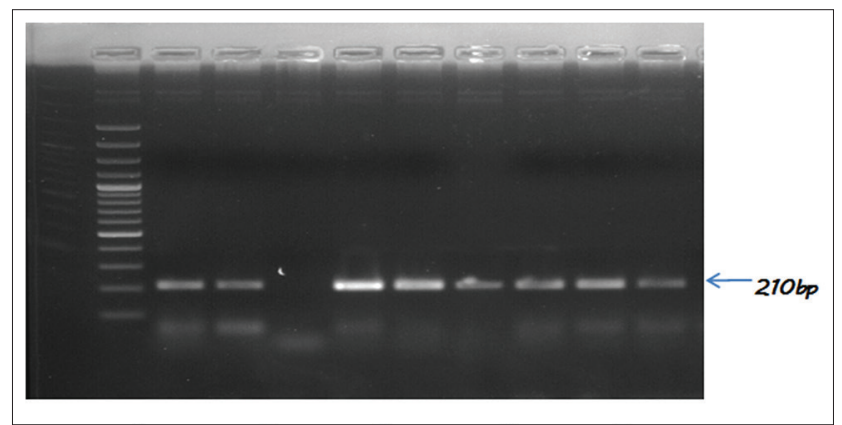

Figure-2: Polymerase chain reaction assay for detection of tetA gene of Salmonella isolates. Lane 1: TrackIt ${ }^{\mathrm{TM}}$ 100bp DNA ladder. Lane 2: Positive control (NIFL1). Lane 3: Positive sample. Lane 4: Negative control. Lanes 5-10: Positive samples.

Table-2: Phenotypic antimicrobial resistance pattern of Salmonella spp.

\begin{tabular}{|c|c|c|c|c|c|}
\hline \multirow[t]{2}{*}{ S. No. } & \multicolumn{2}{|c|}{ Antimicrobial agent } & \multicolumn{3}{|c|}{ Susceptibility of Salmonella isolate (\%) } \\
\hline & & & Sensitive & Intermediate & Resistance \\
\hline 1 & Gen10 & Gentamicin & 88.10 & 4.76 & 7.14 \\
\hline 2 & AZM15 & Azithromycin & 52.38 & 26.19 & 21.43 \\
\hline 3 & CZX30 & Ceftizoxime & 23.81 & 40.48 & 35.71 \\
\hline 4 & AK30 & Amikacin & 95.24 & 0.00 & 4.76 \\
\hline 5 & AMC30 & Amoxyclav & 83.33 & 2.38 & 14.29 \\
\hline 6 & NX10 & Norfloxacin & 64.29 & 9.52 & 26.19 \\
\hline 7 & 030 & Oxytetracycline & 2.38 & 0.00 & 97.62 \\
\hline 8 & Ex10 & Enrofloxacin & 59.52 & 26.19 & 14.29 \\
\hline 9 & CIP5 & Ciprofloxacin & 64.29 & 16.67 & 19.05 \\
\hline 10 & $\mathrm{~S} 10$ & Streptomycin & 66.67 & 16.67 & 16.67 \\
\hline 11 & CL10 & Colistin & 83.33 & 0.00 & 16.67 \\
\hline 12 & $\mathrm{C} 30$ & Chloramphenicol & 95.24 & 0.00 & 4.76 \\
\hline 13 & СТX30 & Cefotaxime & 54.76 & 30.95 & 14.29 \\
\hline 14 & CAZ30 & Ceftazidime & 100.00 & 0.00 & 0.00 \\
\hline 15 & AMP10 & Ampicillin & 78.57 & 0.00 & 21.43 \\
\hline 16 & N30 & Neomycin & 11.90 & 0.00 & 88.10 \\
\hline 17 & E15 & Erythromycin & 0.00 & 16.67 & 83.33 \\
\hline 18 & TE30 & Tetracycline & 21.43 & 0.00 & 78.57 \\
\hline 19 & DO30 & Doxycycline & 0.00 & 0.00 & 100.00 \\
\hline
\end{tabular}


Table-3: Antibiotic resistance and virulence marker gene detected in different Salmonella serotypes.

\begin{tabular}{|c|c|c|c|c|c|c|c|c|}
\hline \multirow[t]{2}{*}{ S. No. } & \multirow[t]{2}{*}{ Source of isolate } & \multirow[t]{2}{*}{ Sample code } & \multirow[t]{2}{*}{ Serogroup } & \multicolumn{4}{|c|}{ Antibiotic resistance marker } & \multirow{2}{*}{$\begin{array}{c}\text { Virulence marker } \\
\text { invA }\end{array}$} \\
\hline & & & & $b^{\prime} a_{\text {TEM }}$ & tetA & tetB & CTX-M & \\
\hline 1 & Cloacal swab & NICS9 & S. Virchow & - & + & - & - & + \\
\hline 2 & Litter & NIFL1 & S. Newport & - & + & - & - & + \\
\hline 3 & Litter & NIFL9 & S. Virchow & - & + & - & - & + \\
\hline 4 & Feces & NIF8 & S. Virchow & - & + & - & - & + \\
\hline 5 & Drinker & NIDR7 & S. Virchow & - & + & - & - & + \\
\hline 6 & Drinker & NIDR6 & S. Typhimurium & - & + & - & - & + \\
\hline 7 & Worker hand & NIWH6 & S. Typhimurium & + & + & - & - & + \\
\hline 8 & Litter & PIL1 & S. Virchow & - & + & - & - & + \\
\hline 9 & Feces & PIF7 & S. Virchow & - & + & - & - & + \\
\hline 10 & Drinking water & PIDW5 & S. Typhimurium & - & + & - & - & + \\
\hline 11 & $\begin{array}{l}\text { Worker hand } \\
\text { (evisceration) }\end{array}$ & RCWH3 & S. Virchow & - & + & - & - & + \\
\hline 12 & $\begin{array}{l}\text { Carcass contact } \\
\text { platform }\end{array}$ & RCCP5 & Salmonella Newport & - & + & - & - & + \\
\hline 13 & Chopping board & RCCB1 & S. Virchow & - & + & - & - & + \\
\hline 14 & Chopping board & RCCB3 & S. Virchow & - & + & - & - & + \\
\hline 15 & Knife & RCKS4 & S. Newport & + & + & - & - & + \\
\hline 16 & Post defeathering & RCPD4 & S. Virchow & + & + & - & - & + \\
\hline 17 & Post defeathering & RCPD3 & S. Virchow & - & + & - & - & + \\
\hline 18 & Post evisceration & RCPE2 & S. Virchow & - & + & - & - & + \\
\hline 19 & Post evisceration & RCPE3 & S. Virchow & - & + & - & - & + \\
\hline 20 & Post evisceration & RCPWC2 & S. Virchow & - & + & - & - & + \\
\hline 21 & $\begin{array}{l}\text { Neck skin of } \\
\text { eviscerated bird } \\
\text { carcass }\end{array}$ & RCNE2 & S. Virchow & - & + & - & - & + \\
\hline 22 & $\begin{array}{l}\text { Defeathering } \\
\text { machine }\end{array}$ & SCDM4 & S. Newport & + & + & - & - & + \\
\hline 23 & $\begin{array}{l}\text { Worker hand } \\
\text { (evisceration) }\end{array}$ & SCWH4 & S. Virchow & - & + & - & - & + \\
\hline 24 & Chopping board & SCCB5 & S. Typhimurium & - & + & - & - & + \\
\hline 25 & Knife swap & SCKS4 & S. Virchow & - & + & - & - & + \\
\hline 26 & Post defeathering & SCPD2 & S. Virchow & - & + & - & - & + \\
\hline 27 & Post evisceration & SCPE4 & S. Virchow & - & + & - & - & + \\
\hline 28 & $\begin{array}{l}\text { Neck skin of } \\
\text { eviscerated bird } \\
\text { carcass }\end{array}$ & SCNC4 & S. Virchow & - & + & - & - & + \\
\hline 29 & $\begin{array}{l}\text { Worker hand } \\
\text { (evisceration) }\end{array}$ & ACWH6* & S. Typhimurium & + & + & - & - & + \\
\hline 30 & Deboning cone & ACDC6 & S. Newport & - & + & - & - & + \\
\hline 31 & Raw meat & FPRM1 & S. Newport & - & + & - & - & + \\
\hline Total & & & & $\begin{array}{c}05 \\
(16.12)\end{array}$ & $\begin{array}{c}31 \\
(100)\end{array}$ & 00 & 00 & 31 \\
\hline
\end{tabular}

*Isolate (ACWH6) received gene bank accession number NCBI GenBank MG844415. S. Virchow= Salmonella Virchow, S. Typhimurium=Salmonella Typhimurium, S. Newport=Salmonella Newport

potential threat to public health. This study demonstrated that Salmonella isolates could able to acquire resistance. Resistance pattern varied from isolates to isolates, but $100.00,97.62,88.10$, and $83.33 \%$ isolates showed resistance to Doxycycline, Oxytetracycline, Neomycin, and Erythromycin, respectively. These resistant isolates in the poultry environment might work as a potential reservoir for transfer of resistant genes into other highly infectious Gram-negative pathogens present in the poultry environment.

Similar results were reported by Ishihara et al. [19] with respect to Oxytetracycline (82.0\%). However, neomycin resistance pattern has comparable finding with Carramiñana et al. [20] who reported $53.4 \%$ resistance to neomycin, while in contrast to the findings of Poppe et al. [21] who observed resistance $<2 \%$ in Salmonella isolates.

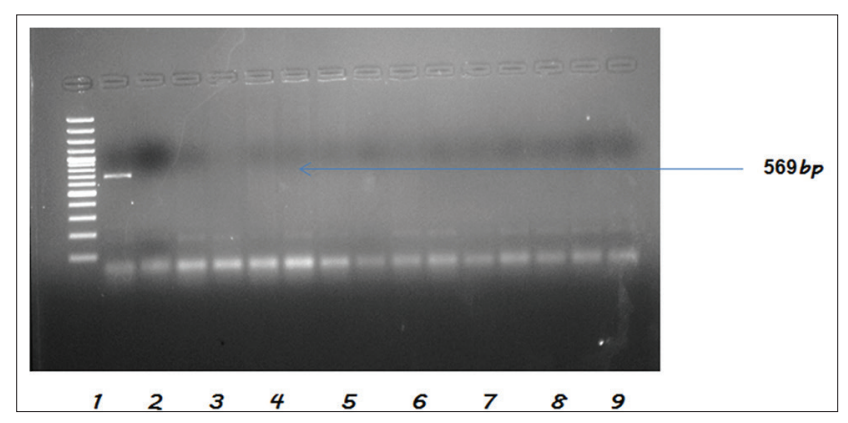

Figure-3: Polymerase chain reaction assay for the detection of tetB gene of Salmonella isolates. Lane 1: TrackIt $^{\top M}$ 100bp DNA ladder.Lane 2: Standard positive control of Salmonella spp. Lane 3: Negative control. Lanes 4-16: Negative samples.

In the present study, resistance $<30 \%$ was recorded to antimicrobials, namely Norfloxacin, Ampicillin, 


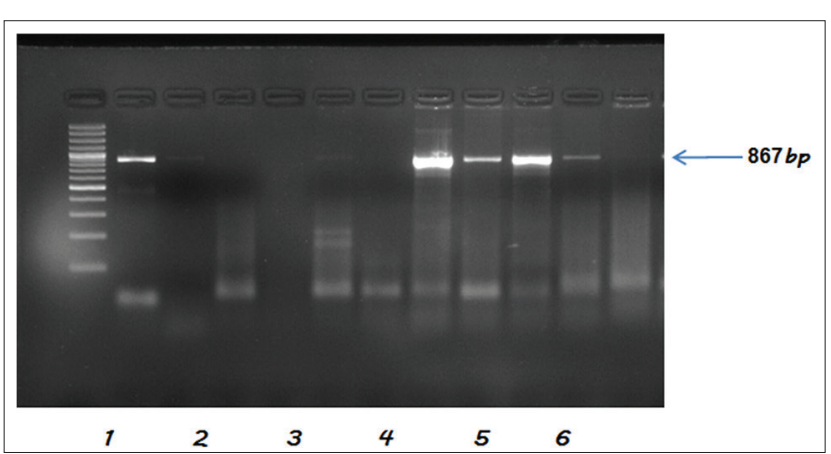

Figure-4: Polymerase chain reaction assay for the detection of bla ${ }_{\text {TEM }}$ gene of Salmonella isolates. Lane 1: TrackIt ${ }^{\mathrm{TM}}$ 100bp DNA ladder. Lane 2: Positive control (NIFL1). Lanes 3-7: Negative samples. Lanes 8-11: Positive samples. Lane 12: Negative samples.

Azithromycin, Ciprofloxacin, Colistin, Streptomycin, Cefotaxime, Enrofloxacin, Amoxyclav, Gentamicin, Chloramphenicol, Amikacin, and Ceftazidime. In the study, Salmonella isolates were found resistant to Ampicillin (21.43\%), Amoxyclav (14.29\%), and Cefotaxime $(14.19 \%)$ which is a rising concern for India because increased use of $\beta$-lactam antibiotics to treat enteric infection, Salmonella spp. might be acquiring resistance to third-generation cephalosporin antibiotic in different parts of the world and leading to clinical treatment failure [22]. Isolates were susceptible to Amikacin (95.24\%), Ceftazidime (100.00\%), and Chloramphenicol (95.24\%) suggested that limited use and effective control by farmers on these compounds are associated with high susceptibility.

Scur et al. [23] found approximately $55 \%$ of resistance to Amoxicillin plus Clavulanic acid, Cefotaxime, Ceftazidime, Amikacin, and Norfloxacin, while Ghazaey and Mirmomeni [24] observed 70-100\% resistance to Gentamicin, Cefotaxime, Streptomycin, and Amoxicillin. Abunna et al. [25] observed 100\% sensitivity to gentamicin and ciprofloxacin, whereas Ghoddusi et al. [26] observed it to Ampicillin, Cefazolin, Cefotaxime, Cefixime, Ceftriaxone, Enrofloxacin, Difloxacin, and Gentamicin which is found not in accordance with the observations of the present study.

Various serovars such as Salmonella Enteritidis, $S$. Typhimurium, $S$. Virchow, and $S$. Newport are important nontyphoidal causes of human salmonellosis caused by consumption of contaminated poultry products [26]. More than 53 serovars have been reported from India, and this number is on ever increasing. Various research workers isolated similar serotypes from poultry farm and processing environment, but the occurrence of $S$. Virchow (65.66) in the current study is higher than the previously isolated report [27]. Similar findings were reported by Khanna [7] who found $S$. Virchow (48\%) and $S$. Typhimurium (24\%), followed by $S$. Infantis $(13 \%), S$. Indiana $(7 \%)$, $S$. Enteritidis, and $S$. Hadar (4\% each) in samples collected from retail meat shops in New Delhi. Recently, research workers isolated $S$. Newport from chicken meat $[28,29]$. Report of $S$. Newport in a poultry farm and processing environment is a serious issue, and rapid rise of MDR Salmonella serovar Newport isolates over the past decade as important causes of human Salmonellosis [30].

Several serotypes are consistently found at a higher incidence, and the distribution of Salmonella serotypes from poultry sources varies geographically and changes over a period of time [31]. The high rates of serogroup $S$. Virchow in our studies taken together with previous data may suggest that this serogroup may be more adapted to poultry farm and processing environments under study. A total of 11 isolates remained untypable which were positive by PCR assay for invA gene but negative by serotyping has been termed as untypable. This may be attributed to the presence of rough mutant strains which lack the specific side chains responsible for "O" specificity or some additional abnormalities of the core structure [28].

All the tested Salmonella serotypes were found to carry Tetracycline resistance gene tetA $(100 \%)$ whereas none of them were carrying tet $B$ gene. Whereas, 5 isolates were found positive for bla $_{\text {TEM }}$ $(16.12 \%)$ and none of the isolate was found to carry CTX-M gene. The prevalence of broad-spectrum $\beta$-lactamases resistance $\left(\right.$ bla $\left._{\mathrm{TEM}}\right)$ in the serovars from poultry farm and processing units was not uniformly distributed in samples analyzed. For bla $a_{\text {TEM }}$ gene, two isolates were positive from each of $S$. Typhimurium (NIWH6 and ACWH6) and $S$. Newport (SCDM4 and RCKS4), while one isolate was positive for $S$. Virchow (RCPD4). Uniform distribution of phenotypic Tetracycline resistance (Doxycycline and Oxytetracycline) among all the serovars along with the presence of tetA gene indicates selective pressure on the Salmonella spp. for adopting resistance against Tetracycline group of antibiotics.

The overall occurrence of Tetracycline resistance and broad-spectrum $\beta$-lactamases resistance in Salmonella isolates was 100 and $16.12 \%$, respectively. The findings in the present study regarding tet $A$ and tet $B$ gene were in corroboration with Soufi et al. [10]. On the contrary Lebdah et al. [32] who reported 70 and $20 \%$, prevalence for tet $A$ and tet $B$, respectively.

The tet $A$ gene associated with tetracycline efflux pumps was reported to be predominant in Salmonella, and Escherichia coli isolates from livestock and food animals, and it may present in mobile elements and is acquired by bacteria through horizontal gene transfer [33,34]. Result confirms good phenotypic and genotypic correlation for Tetracycline resistance among Salmonella isolates.

The findings for $b l a_{\text {TEM }}$ gene in the current study are supported by the results of other researchers [35]. The cefotaximases (CTX-M-type extended-spectrum beta-lactamases) have become the most widespread $\beta$-lactamases over the past few years. In the current study, none of the serotypes was found to be positive for gene encoding CTX-M. Our report is in agreement 
with Wittum et al. [36], whereas our results are contradicting with reports of Riano et al. [37], who reported Salmonella serovars with the CTX-M gene, which might be due to the influence of the genomic environment on local dissemination of resistance genes among different bacterial genera [38] and antimicrobials that could not be extensively used among poultry which may confer selective pressure to acquire resistance.

Kodimalar et al. [39] reported that occurrence of tetracycline residue in feed samples reflects the extensive use of chlortetracycline agent in chicken production systems. Van Boeckel et al. [40] reported, in Asia, that antimicrobial consumption in chicken is expected to grow by $129 \%$ by 2030 , wherein currently in India the issue of overuse of these antibiotics is of particular significance with South Coast of India, while the cities of Mumbai and Delhi are becoming antimicrobial consumption hotspots.

In the present study, phenotypic resistance to Tetracycline group of antibiotics with the presence of tetA gene is in correlation. This indicates selective pressure on Salmonella isolates leading to an increase in the prevalence of Tetracycline resistance posing a risk to human and animal health. However, drug-susceptible Salmonellae can also become resistant by acquiring drug resistance plasmids from other enteric pathogens in the intestinal tract of patients [41].

Our results confirm dissemination of multidrug-resistant $S$. Virchow, $S$. Typhimurium, and $S$. Newport from farm to processing environment which may pose a serious risk to human health. These serotypes may affect human by causing nontyphoidal Salmonellosis. Information on daily dose, duration of treatment, number of animals treated, and consumption data may be useful to relate the simultaneous existence of antimicrobial resistance [42]. In the present study, unfortunately, supportive information regarding antimicrobial usage of various other antimicrobials was not available; therefore, it was not possible to associate the observed resistances to use of antimicrobials.

\section{Conclusion}

This study revealed a significant rise in Tetracycline resistance with presence of tetA gene in Salmonella spp. indicating selective pressure for adopting resistance against tetracycline group of antibiotics. Dissemination of multidrug-resistant $S$. Virchow, $S$. Typhimurium, and $S$. Newport from farm to processing environment may pose a serious risk to human health, and these serotypes may affect human by causing nontyphoidal Salmonellosis.

\section{Authors' Contributions}

RNW designed the experiment under the supervision of AMP. RJZ and RVG supervised work. Media preparation, sample collection, and bacteriological analysis were performed by RNW and VMV. Molecular work was performed by RNW, ZND, and
AD. All authors participated in the draft and revision of the manuscript. All authors read and approved the final manuscript.

\section{Acknowledgments}

The authors are highly thankful to Associate Dean, Bombay Veterinary College for providing facilities. The authors are also thankful to Vista Processed Foods Ltd. for help in sample collection and financial help during this study.

\section{Competing Interests}

No persons from Vista Processed Foods Ltd. were involved at any stage of the study.

\section{References}

1. Kiilholma, J. (2007) Food-Safety Concerns in the Poultry Sector of Developing Countries http://www.fao.org/AG/ againfo/home/events/bangkok2007/docs/part2/2_8.pdf. Last accessed on 12-10-2018.

2. Yang, H., Dey, S., Buchanan, R. and Biswas, D. (2014) Pests in Poultry, Poultry Product-Borne Infection and Future Precautions Practical Food Safety: Contemporary Issues and Future Directions. $1^{\text {st }}$ ed. John Wiley \& Sons, Ltd. Sussex. p535-552.

3. Simmons, M., Fletcher, D.L., Cason, J.A. and Berrang, M.E. (2003) Recovery of Salmonella from retail broilers by a whole-carcass enrichment procedure. J. Food Prot., 66(3): 446-450.

4. Bryan, F.L. and Doyle, M.P. (1995) Health risks and consequences of Salmonella and Campylobacter jejuni in raw poultry. J. Food Prot., 58(3): 326-344.

5. Centers for Disease Control and Prevention. (2012) Available from: http://www.cdc.gov/Salmonella/general. Last accessed on 12-10-2018.

6. Guibourdenche, M., Roggentin, P., Mikoleit, M., Fields, P.I., Bockemuhl, J., Grimont, P.A. and Weill, F.X. (2010) Supplement 2003-2007 (No. 47) to the white-kauffmann-le minor scheme. Res. Microbiol., 161(1): 26-29.

7. Khanna, H.R. (2009) Prevalence of Salmonella in Broiler Retail Meat Shops in New Delhi, India. A Thesis Submitted To Chiang Mai University And Freie Universität Berlin in Partial Fulfilment of the Requirements for the Degree of Master of Veterinary Public Health.

8. Apata, D.F. (2009) Antibiotic resistance in poultry. Int. J. Poult. Sci., 8(4): 404-408.

9. Mazaheri, N.F.R., Heuzenroeder, M.W. and Barton, M.D. (2011) Antimicrobial and heavy metal resistance in commensal enterococci isolated from pigs. Vet. Microbiol., 148(2-4): 276-282.

10. Soufi, L., Saenz, Y., Toro, M., Abbassi, M.S., RojoBezares, B., Vinue, L., Bouchami, O., Touati, A., Hassen, A.B., Hammami, S. and Torres, C. (2012) Phenotypic and genotypic characterization of Salmonella enterica recovered from poultry meat in Tunisia and identification of new genetic traits. Vector Borne Zoonotic Dis., 12(12): 10-16.

11. UCS: Union of Concerned Scientists. (2001) Hogging It! Estimates of Antimicrobial Abuse in Livestock. In: Mellon, M., Benbrook, C. and Benbrook, K.L., editors. USC, Cambridge, MA.

12. IS 5887. (1999) Methods for Detection of Bacteria Responsible for Food Poisoning Part 3: General Guidance on Methods for the Detection of Salmonella.

13. Rahn, K., De Grandis, S.A., Clarke, R.C., McEwen, S.A., Galán, J.E., Ginocchio, C., Curtiss, R. and Gyles, C.L. (1992) Amplification of an invA gene sequence of Salmonella typhimurium by polymerase chain reaction as a specific method of detection of Salmonella. Mol. Cell. Probes., 6(4): 271-279. 
14. CLSI. (2017) Clinical and Laboratory Standards Institute. M100-S17: Performance Standards for Antimicrobial Susceptibility Testing. $27^{\text {th }}$ ed. CLSI Informational Supplement. Clinical and Laboratory Standards Institute, Wayne, PA.

15. Bhattacharjee, A., Sen, M.R., Pradyot, S.A. and Nath, P.G. (2007) Detection of OXA-2 group extended-spectrum- $\beta$-lactamase-producing clinical isolates of Escherichia coli from India. J. Antimicrob. Chemother., 60(3): 703-704.

16. Fonseca, E.L., Mykytczuk, O.L., Asensi, M.D., Reis, E.M., Ferraz, L.R., Paula, F.L., Ng, L.K. and Rodrigues, D.P. (2006) Clonality and antimicrobial resistance gene profiles of multidrug-resistant Salmonella enterica serovar infantis isolates from four public hospitals in Rio de Janeiro. Brazil. J. Clin. Microbiol., 44(8): 2767-2772.

17. Boyd, D.A., Tyler, S., Christianson, S., McGeer, A., Muller, M.P., Willey, B.M., Bryce, E., Gardam, M. and Nordmann, P.M.R. (2004) Mulvey and Canadian nosocomial infection surveillance program, health Canada complete nucleotide sequence of a 92-kilobase plasmid harboring the CTX-M-15 extended-spectrum beta-lactamase involved in an outbreak in long-term-care facilities in Toronto, Canada. Antimicrob. Agents Chemother., 48(10): 3758-3764.

18. Andersson, D.I. (2003) Persistence of antibiotic-resistant bacteria. Curr. Opini. Microbiol., 6(5): 452-456.

19. Ishihara, K., Takahashi, T., Morioka, A., Kojima, A., Kijima, M., Asai, T. and Tamura, Y. (2009) National surveillance of Salmonella enterica in food-producing animals in Japan. Acta Vet. Scand., 51(1): 35.

20. Carramiñana, J.J., Rota, C., Agustín, I. and Herrera, A. (1997) High prevalence of multiple resistance to antibiotics in Salmonella serovars isolated from a poultry slaughterhouse in Spain. Vet. Microbiol., 104(1-2): 133-139.

21. Poppe, C., McFadden, K.A. and Demczuk, W.H. (1996) Drug resistance, plasmids, biotypes and susceptibility to bacteriophages of Salmonella isolated from poultry in Canada. Int. J. Food Microbiol., 30(3): 325-344.

22. Jiang, H.X., Song, L., Liu, J., Zhanga, X.H., Rena, Y.N., Zhanga, W.H., Zhanga, J.Y., Liua, Y.H., Webber, M.A., Ogboluc, D.O., Zenga, Z.L. and Piddock, L.J.V. (2014) Multiple transmissible genes encoding fluoroquinolone and third-generation cephalosporin resistance co-located in non-typhoidal Salmonella isolated from food-producing animals in China. Int. J. Antimicrob. Agents, 43(3): 242-247.

23. Scur, M.C., Pinto, F.G.S., De Bona, E.A.M., Weber, L.D., Alves, L.F.A. and de Moura, A.C. (2014) Occurrence and antimicrobial resistance of Salmonella serotypes isolates recovered from poultry of Western Paraná. Brazil. Afr. J. Agric. Res., 9(9): 823-830.

24. Ghazaey, S. and Mirmomeni, M.H. (2012) Microbialresistant Salmonella enteritidis isolated from poultry samples. Rep. Biochem. Mol. Biol., 1(1): 10-13.

25. Abunna, F., Bedasa, M., Beyene, T., Ayana, D., Mamo, B. and Duguma, R. (2016) Salmonella: Isolation and antimicrobial susceptibility tests on isolates collected from poultry farms in and around Modjo, Central Oromia, and Ethiopia. J. Anim. Poult. Sci., 5(2): 21-35.

26. Ghoddusi, A., Nayeri, F.B., Karimi, V., Ashrafi, T.I., Moulana, Z. and Zahraei, S.T. (2015) Molecular identification of Salmonella infantis isolated from backyard chickens and detection of their resistance genes by PCR. Indian $J$. Vet. Res., 16(3): 293-297.

27. Mir, I.A., Kashyap, S.K. and Maherchandani, S. (2015) Isolation, serotype diversity and antibiogram of Salmonella enterica isolated from different species of poultry in India. Asian Pac. J. Trop. Biomed., 5(7): 561-567.

28. Kaushik, P, Kumari, A.S., Bharti, S.K. and Dayal, S. (2014)
Isolation and prevalence of Salmonella from chicken meat and cattle milk collected from local markets of Patna, India. Vet. World, 7(2): 62-65.

29. Machado, S.C.A., Pereira, V.L.A., Aquino, M.H.C., Santos, A.F.M., Rodrigues, D.P., Giombelli, A. and Nascimento, E.R. (2017) Serotyping and genotyping of Salmonella strains isolated from broilers, chicken carcasses before and after chilling, and frozen chicken breasts produced in the states of Mato Grosso do Sul and Santa Catarina, Brazil. Brazil. J. Poult. Sci., 19(1): 135-142.

30. Centers for Disease Control and Prevention (2005) Salmonella Surveillance. Annual Summary 2004. Atlanta, GA.

31. Myint, M.S. (2004) Epidemiology of Salmonella Contamination of Poultry Meat Products: Knowledge Gaps in the Farm to Store Products. Ph.D. Dissertation. University of Maryland, Maryland, USA. p86-98.

32. Lebdah, M.A., Mohammed, W.M., Eid, S. and Hamed, R.I. (2017) Molecular detection of some antimicrobial resistance genes in Salmonella Species isolated from commercial layers in Egypt. Zag. Vet. J., 45(1): 29-38.

33. Jouini, A., Ben, S.K., Sáenz, Y., Klibi, N., Costa, D., Vinue, L., Zarazaga, M., Boudabous, A. and Torres, C. (2009) Detection of multiple-antimicrobial resistance and characterization of the implicated genes in Escherichia coli isolates from foods of animal origin in Tunisia. J. Food Protect., 72(5): 1082-1088.

34. Soufi, L., Abbassi, M.S., Sáenz, Y., Vinué, L., Somalo, S., Zarazaga, M., Abbas, A. and Dbaya, R. (2009) Prevalence and diversity of integrons and associated resistance genes in Escherichia coli isolates from poultry meat in Tunisia. Foodborne Pathog. Dis., 6(3): 1067-1073.

35. Sharkawy, H., Tahoun, A., El Galiel, A., El Gohary, A., El Abasy, M., El Khayat, F., Gillespie, T., Kitade, Y., Hafez, H.M., Neubauer, H. and El Adawy, H. (2017) Epidemiological, molecular characterization and antibiotic resistance of Salmonella enterica serovars isolated from chicken farms in Egypt. Gut. Pathog., 9(1): 8.

36. Wittuma, T.E., Mollenkopfa, D.F. and Erdmanb, M.M. (2012) Detection of Salmonella enterica isolates producing CTX-M cephalosporinase in U.S. Livestock populations. Appl. Environ. Microbiol., 78(20): 7487-7491.

37. Riano, I., Moreno, M.A., Teshager, T., Saenz, Y., Dominguez, L. and Torres, C. (2006) Detection and characterization of extended-spectrum b-lactamases in Salmonella enterica strains of healthy food animals in Spain. $J$. Antimicrob. Chemother., 58(4): 844-847.

38. Oliver, A., Coque, T.M. and Alonso, D. (2005) CTX-M10 linked to a phage-related element is widely disseminated among Enterobacteriaceae in a Spanish hospital. Antimicrob. Agents Chemother., 49(4): 1567-1571.

39. Kodimalar, K., Rajini, R.A., Ezhilvalavan, S. and Sarathchandra, G. (2014) A survey of chlortetracycline concentration in feed and its residue in chicken egg in commercial layer farms. J. Biosci., 39(3): 425-431.

40. Van Boeckel, T.P., Brower, C. and Gilbert, M. (2015) Global trends in antimicrobial use in food animals. Proc. Nat. Acad. Sci., 112(18): 5649-5654.

41. Su, L.H., Chiu C.H, Chu, C. and Ou, J.T. (2004) Antimicrobial resistance in nontyphoid Salmonella serotypes: A global challenge. Clin. Infect. Dis., 39(4): 546-551.

42. EFSA. (2015) EFSA Explains Zoonotic Diseases - Salmonella. European Food Safety Authority, Consulted. Available from: http://www.efsa.europa.eu/sites/ default/files/corporate_publications/files/factsheetSalmonella.pdf.Last accessed on 9-10-2018.

\section{$* * * * * * * *$}

